\title{
Biochemical and Physiological Properties of Methionyl-sRNA Synthetase Mutants of Salmonella typhimurium
}

\author{
By T. S. GROSS* AND R. J. ROWBURY \\ Department of Botany and Microbiology, University College London, \\ Gower Street, London W.C.I
}

(Accepted for publication 2 November 1970)

\begin{abstract}
SUMMARY
Two methionine auxotrophs (metG) of Salmonella typhimurium with the structural genes of the regulon intact have been studied. They possessed abnormal growth kinetics and the effect of the met $G$ mutation on protein, ribonucleic acid and DNA synthesis suggested that these strains were impaired in their ability to synthesize protein; since they were able to synthesize methionine, but still required it for growth, they might have been defective in methionine activation for protein synthesis. To test this, the activity of methionyl-sRNA synthetase (L-methionine: sRNA ligase (AMP) EC 6. I I I I0) was determined in enzymic extracts of wild-type and met $G$ strains. By using an acylation reaction the activation of methionine for protein synthesis was shown to be very decreased in $m e t G$ extracts and this was reflected in vivo by a decreased level of charged methionyl-sRNA in mutant bacteria; in the pyrophosphate exchange assay mutants showed greatly increased $K_{m}$ (methionine) values. The release of $\left[{ }^{3} \mathrm{H}\right]$ methionine from $\left[{ }^{3} \mathrm{H}\right]$ methionylsRNA was catalysed by wild-type extract, provided that pyrophosphate was present in the assay mixture, but not by the mutant extract. These results are discussed in relation to the two-part reaction catalysed by methionylsRNA synthetase. Mutant and wild-type enzyme behaviour differed at different $\mathrm{pH}$ values but not when subjected to chromatography on DEAEcellulose or gel-filtration on Sephadex-G20o. MetG mutants grown with limiting methionine had decreased values of all the biosynthetic enzymes except cystathionase, which was apparently de-repressed, suggesting that methionyl-sRNA was not the co-repressor for the methionine biosynthetic pathway.
\end{abstract}

\section{INTRODUCTION}

Recently, bacterial mutants which possess defective aminoacyl-sRNA synthetases for various amino acids have been isolated. Such mutants have been isolated on the basis of temperature sensitivity, e.g. valine (Eidlic \& Neidhardt, 1965), alanine (Yanif, Jacob \& Gros, I965), phenylalanine (Eidlic \& Neidhardt, I965); analogue resistance, e.g. histidine (Roth \& Ames, 1966), phenylalanine (Fangman \& Neidhardt, I964); as naturally occurring variants, e.g. glycine (Böck \& Neidhardt, I966; Neidhardt, 1966); and as amino acid-requiring auxotrophs, e.g. tryptophan (Hiraga, Ito, Hamada \& Yura, 1967). MetG mutants of Salmonella typhimurium were originally isolated as methionine bradytrophs by Smith \& Childs (1966). All the methionine biosynthetic enzymes were shown to be present but at apparently decreased values (Foster, cited by Smith \& Childs, I966) which originally led to the suggestion that

* Present address: Genetics Department, The University, Western Bank, Sheffield, Sio 2TN. 
met $G$ mutants were super-repressed for the methionine biosynthetic enzymes. The present work shows that the requirement for methionine is due to an altered methionylsRNA synthetase.

In recent years, evidence that some amino acids must be attached to their specific sRNAs before they are able to bring about repression of their biosynthetic enzymes has been put forward. Perhaps the best-known example is that of histidine, where mutation in either of two genes, hisS or hisR, results in de-repression of the histidine biosynthetic enzymes (Roth \& Ames, 1966; Silbert, Fink \& Ames, 1966). In both cases there is a decrease in the amount of histidyl-sRNA formed, due to an increased $K_{m}$ (histidine) of the histidyl-sRNA synthetase (his $S$ ) or a decrease in the amount of active sRNA ${ }_{\text {bis }}$ synthesized by the mutant bacteria (hisR). Since met $G$ mutants have an altered methionyl-sRNA synthetase, the amounts of the methionine biosynthetic enzymes in these strains were studied. Some of these results have previously been reported briefly (Gross \& Rowbury, 1969).

\section{METHODS}

Organisms. All the strains of Salmonella typhimurium used in this work were maintained on slopes of Oxoid nutrient agar, subcultured monthly and stored at $4^{\circ}$ after incubation for $18 \mathrm{~h}$. at $37^{\circ}$. The mutants met $G_{3} I 9$ and $m e t G_{4} I 9$ were isolated from the wild-type strain LT-2 and an Hfr derivative of LT-2 (HfrB2) was used as wild-type in these experiments. The mutant metB23 is a methionine auxotroph and lacks the enzyme cystathionine synthetase. All strains were supplied by Dr D. A. Smith.

Growth of organisms. Organisms were grown on the glucose mineral salts medium (MM) of Davis \& Mingioli (1950) supplemented with 0.04 mM-DL-methionine for the growth of methionine mutants. Conditions for growth, harvesting and preparation of enzymic extracts were as described by Rowbury \& Woods (1961).

Phage propagation and assay. Phage $\mathrm{P}_{22} \mathrm{~L}_{4}$ is a virulent mutant of phage $\mathrm{P}_{22}$ (Smith \& Levine, 1967) and was provided by Dr D. A. Smith. It was propagated on strain metG 319 . Phage $\left(5 \times 10^{4}\right.$ infective particles $/ \mathrm{ml}$.) were added to organisms growing exponentially in nutrient broth. Incubation was for $120 \mathrm{~min}$. at $37^{\circ}$, after which cultures were shaken with a few drops of chloroform. Cell debris was removed by centrifugation ( $3000 \mathrm{~g}$ for $10 \mathrm{~min}$.) and the preparations stored over chloroform. For phage assay, samples were diluted in phosphate buffer $(0.05 \mathrm{M}, \mathrm{pH} 7.4)$ and portions added to tubes of $4 \mathrm{ml}$. soft agar $\left(0.2 \% \mathrm{MgCl}_{2}, \mathrm{I} \%\right.$ Oxoid broth no. $2,0.3 \%$ $\mathrm{NaCl}, 0.75 \%$ Difco Bacto agar). After adding $3 \times 10^{7}$ indicator bacteria (strain met $\left.G_{319}\right)$ the soft agar was poured on to a basal agar $(25 \mathrm{ml}$.) consisting of I \% Trypticase agar base, $1.4 \%$ Difco Bacto agar, $0.5 \% \mathrm{NaCl}$. Plates were incubated at $37^{\circ}$ overnight.

Incorporation of $\left[{ }^{14} \mathrm{C}\right]$ phenylalanine into protein. This was followed by a method based on that of Neale \& Tristram (1963). Exponentially growing cultures in MM medium, supplemented where necessary, were harvested and washed with two culture volumes of MM medium. The washed bacteria were resuspended in Io $\mathrm{ml}$. fresh MM medium at equivalents of $\mathrm{I} 25 \mu \mathrm{g}$. dry weight bacteria $/ \mathrm{ml}$. and incubated with aeration at $37^{\circ}$. Incorporation was initiated by addition of $\left[{ }^{14} \mathrm{C}\right]$ phenylalanine $(\mathrm{I} \cdot 25 \mu \mathrm{Ci}, 7 \mathrm{mC} / \mathrm{mM})$ and I ml. samples were transferred at intervals into an equal volume of $10 \%$ trichloroacetic acid and allowed to stand for $30 \mathrm{~min}$. at room temperature. Samples were 
heated at $100^{\circ}$ for $30 \mathrm{~min}$. to remove nucleic acids, cooled and filtered through a Millipore filter (type HA). The precipitate was washed with two $2 \mathrm{ml}$. quantities of $5 \%$ trichloroacetic acid (TCA), followed by a few drops of ether, mounted on an aluminium planchet and counted with a thin end-window Geiger-Müller tube (I.D.L. Ltd, Reading, Berkshire).

Incorporation of $\left[{ }^{14} \mathrm{C}\right]$ uracil into $R N A$. The method was essentially similar to that used to follow incorporation of $\left.{ }^{[4} \mathrm{C}\right]$ phenylalanine into protein except that samples were not heated. The incubation mixture contained $0.6 \mu \mathrm{Ci},\left[{ }^{14} \mathrm{C}\right]$ uracil $(50 \mathrm{mCi} / \mathrm{mM})$. After standing for $30 \mathrm{~min}$. at room temperature, samples were filtered and counted as before.

Incorporation of $\left[{ }^{3} H\right]$ thymidine into $D N A$. Organisms growing logarithmically in MM medium $+\mathrm{L}$-methionine $(\mathrm{mM})+$ uridine $(\mathrm{I} \cdot 5 \mathrm{mM})+\left[{ }^{3} \mathrm{H}\right]$ thymidine $(2 \mu \mathrm{g} . / \mathrm{ml}$; $0 \cdot \mathrm{I} \mu \mathrm{Ci} / \mu \mathrm{g}$.) were rapidly harvested and washed with cold $\mathrm{MM}$ medium. They were then resuspended at equiv. $50 \mu \mathrm{g}$. dry wt/ml. in an incubation mixture which contained in $5 \mathrm{ml}$. of $\mathrm{MM}$ medium, $7.5 \mu$ moles uridine and $10 \mu \mathrm{g}$. $\left[{ }^{3} \mathrm{H}\right]$ thymidine $(0 \cdot 1 \mu \mathrm{Ci} / \mu \mathrm{g}$.) with L-methionine and/or chloramphenicol ( $100 \mu \mathrm{g} . / \mathrm{ml}$.) added as required. Incubation was with shaking at $37^{\circ}$ and samples were removed at $15 \mathrm{~min}$. intervals into equal volumes of cold Io \% TCA. After standing overnight samples were filtered on Millipore filters (type HA), and after washing the filters with $5 \%$ TCA containing $100 \mu \mathrm{g} . /$ $\mathrm{ml}$. thymidine and drying they were placed in $10 \mathrm{ml}$. of scintillation fluid $(0.6 \%$ butyl PBD in toluene + methanol, $3+\mathrm{I}, \mathrm{v} / \mathrm{v}$ ) and counted.

Induction of D-serine deaminase (D-serine hydrolase (deaminating), EC 4.2.I.I4). Overnight cultures of organisms were used to inoculate $300 \mathrm{ml}$. MM medium with or without $0.1 \mathrm{mM}-\mathrm{DL}-\mathrm{methionine}$ and incubated at $37^{\circ}$. Once bacteria had attained the logarithmic phase of growth a sample was removed and a cell-free extract made, D-serine was then added to the culture flask to $3 \mathrm{~mm}$. Extracts were made after I, 2 and $3 \mathrm{~h}$. and assayed for D-serine deaminase activity. The reaction mixture contained, in a total volume of $2 \mathrm{ml}$., $133 \mu$ moles phosphate buffer ( $\mathrm{pH} 7 \cdot 5$ ), D-serine ( $12 \mu$ moles) and enzyme extract. Incubation was for $20 \mathrm{~min}$. at $37^{\circ}$ and the reaction then stopped by adding $0.5 \mathrm{ml} .25 \%$ trichloroacetic acid. Precipitated protein was removed by centrifugation and pyruvate present in the supernatant fluid estimated by the method of Wijesundera \& Woods (I962).

Assay for amino acid-dependent ATP-pyrophosphate exchange. The activation of methionine was measured by this method and the reaction mixture contained in a volume of I ml., $50 \mu$ moles tris- $\mathrm{HCl}$ buffer ( $\mathrm{pH} 7 \cdot 5$ ), $80 \mu$ moles $\mathrm{MgCl}_{2}, 2 \mu$ moles ATP, $3 \mu$ moles. $\beta$-mercaptoethanol, $2 \mu$ moles [32P]pyrophosphate (I00 to 200 counts/min./nmole), limiting enzyme and various amounts of methionine. Reaction was started by adding extract and after incubation for $15 \mathrm{~min}$. at $37^{\circ}$ protein was precipitated by adding $2 \mathrm{ml} .7 .5 \%$ TCA. After removal of the precipitate, $0.5 \mathrm{ml}$. charcoal suspension ( $10 \%$ Darco $\mathrm{G}_{20}$ in $0 . \mathrm{IO} \mathrm{M}-\mathrm{Na}_{4} \mathrm{P}_{2} \mathrm{O}_{7}$ ) and $4 \mathrm{ml}$. I \% $\mathrm{H}_{3} \mathrm{PO}_{4}$ in $0 \cdot 10 \mathrm{M}-\mathrm{Na}_{4} \mathrm{P}_{2} \mathrm{O}_{7}$ was added to each tube. The charcoal was collected by filtration,

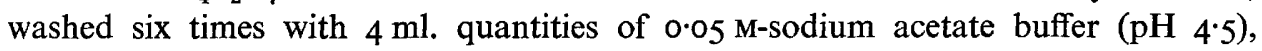
and radioactivity assayed by using a mica end-window Geiger-Müller tube.

Assay for aminoacyl-sRNA formation. The method used to follow methionyl-sRNA formation was based on that of Fangman \& Neidhardt (I964). The reaction mixture contained, in a final volume of $0.5 \mathrm{ml}$., $25 \mu$ moles tris- $\mathrm{HCl}$ buffer $\left(\mathrm{pH}_{7} \cdot 5\right), \mathrm{I}^{\circ} 5 \mu$ mole ATP, I $5 \mu$ mole $\beta$-mercaptoethanol, $4 \mu$ moles $\mathrm{MgCl}_{2}, 0.5 \mu \mathrm{Ci}\left[{ }^{3} \mathrm{H}\right]$ methionine (30 mCi) 
mM), I.7 mg. sRNA and a limiting amount of enzyme. Reaction was started by adding enzymic extract, and after incubation for 5 to $20 \mathrm{~min}$. at $37^{\circ}$ a $0.3 \mathrm{ml}$. sample was withdrawn on to a rectangle of Whatman's I20-drop reaction paper impregnated with casein, and dropped into ice-cold 10 \% TCA. Papers were then treated by the method of Mans \& Novelli (196I) to remove lipid, dried and counted by scintillation in a mixture of $0.6 \%, 2,5$-diphenyloxazole, and $0.01 \%$ I,4-bis-(2,5-phenyloxazolyl) benzene in sulphur-free toluene.

$A M P$-dependent release of methionine from methionyl-sRNA. The release of $\left[{ }^{3} \mathrm{H}\right]$ methionine from $\left[{ }^{3} \mathrm{H}\right]$ methionyl-sRNA was followed by the technique of Hervé \& Chapeville (1963). The reaction mixture contained, in a total volume of $0.5 \mathrm{ml}$., $50 \mu$ moles tris- $\mathrm{HCl}$ buffer ( $\mathrm{pH} 7.5$ ), $8 \mu$ moles $\mathrm{MgCl}_{2}, 2.5 \mu$ moles AMP, $2.5 \mu$ moles $\mathrm{Na}_{4} \mathrm{P}_{2} \mathrm{O}_{7},\left[{ }^{3} \mathrm{H}\right]$ methionyl-sRNA and limiting enzyme. Incubation was at $37^{\circ}$ and $0 . \mathrm{I} \mathrm{ml}$. samples were withdrawn at intervals on to Whatman $120-d r o p$ reaction paper and treated as above.

Assay of the methionine biosynthetic enzymes. The methionine biosynthetic enzymes were assayed as described previously (Rowbury \& Woods, I966; Rowbury, Lawrence \& Smith, I968).

Estimation of in vivo charged $s R N A$. The fraction of methionyl-sRNA existing in a charged form was determined by the method of Böck, Faiman \& Neidhardt (1966), which uses the periodate method to destroy the amino acid-accepting capacity of uncharged sRNA.

DEAE-cellulose chromatography. Crude enzymic extract ( $5 \mathrm{ml}$, , Io $\mathrm{mg}$. protein/ml.) was added to a column $(25 \times$ I cm.) of DEAE-cellulose (Whatman DE I I) and eluted with $400 \mathrm{ml}$. of a linear gradient of $\mathrm{NaCl}(0.05$ to $0.5 \mathrm{M})$ at a flow rate of approximately $30 \mathrm{ml} . / \mathrm{h}$. Eighty $5 \mathrm{ml}$. fractions were collected and assayed for protein and synthetase activity.

Gel filtration on Sephadex G-200. One ml. crude extract (Io mg. protein) was added to the top of a column $(80 \times \mathrm{I} \mathrm{cm}$.) of Sephadex- 200 and eluted with $0.0 \mathrm{I}$ M-tris$\mathrm{HCl}$ buffer ( $\mathrm{pH} 7 \cdot 5)$. Eighty I ml. fractions were collected and assayed for protein and synthetase activity. The void volume of the column was determined by measuring the exclusion of blue dextran; bovine serum albumin was used as a marker protein.

Chemicals. These were usually obtained from British Drug Houses Ltd, Poole, Dorset, and were of 'Analar' grade. Radioactive chemicals were obtained from the Radiochemical Centre, Amersham, Buckinghamshire, and the sRNA used in the assay of methionyl-sRNA synthetase was a gift from the Microbiological Research Establishment, Porton.

Protein determinations. The spectrophotometric method of Layne (1957) was used.

\section{RESULTS}

Growth kinetics of met $G$ mutants. The growth of the met $G$ mutants metG3rg and metG4I9 on different concentrations of DL-methionine was followed in MM medium; the results obtained are presented in Fig. I $(b)$ and I $(c)$ respectively. For comparison, the growth of a methionine auxotroph, metB23, on different methionine concentrations is shown in Fig. I $(a)$. As expected, the growth rate of metB23 did not vary significantly at different methionine concentrations and continued until the exogenous methionine supply had been exhausted. Growth then ceased and the final bacterial 
concentration was approximately proportional to the original concentration of DLmethionine. In contrast, the growth rate of met $G$ mutants varied with methionine concentration.

These results are very like those obtained by Doolittle \& Yanofsky (I968) with a tryptophanyl-sRNA synthetase mutant of Escherichia coli and suggested that met $G$ mutants might be defective in their ability to activate methionine for protein synthesis. It was also possible that met $G$ mutants were altered in the synthesis of S-adenosylmethionine (SAM) so that SAM synthesis was decreased in the absence of methionine.
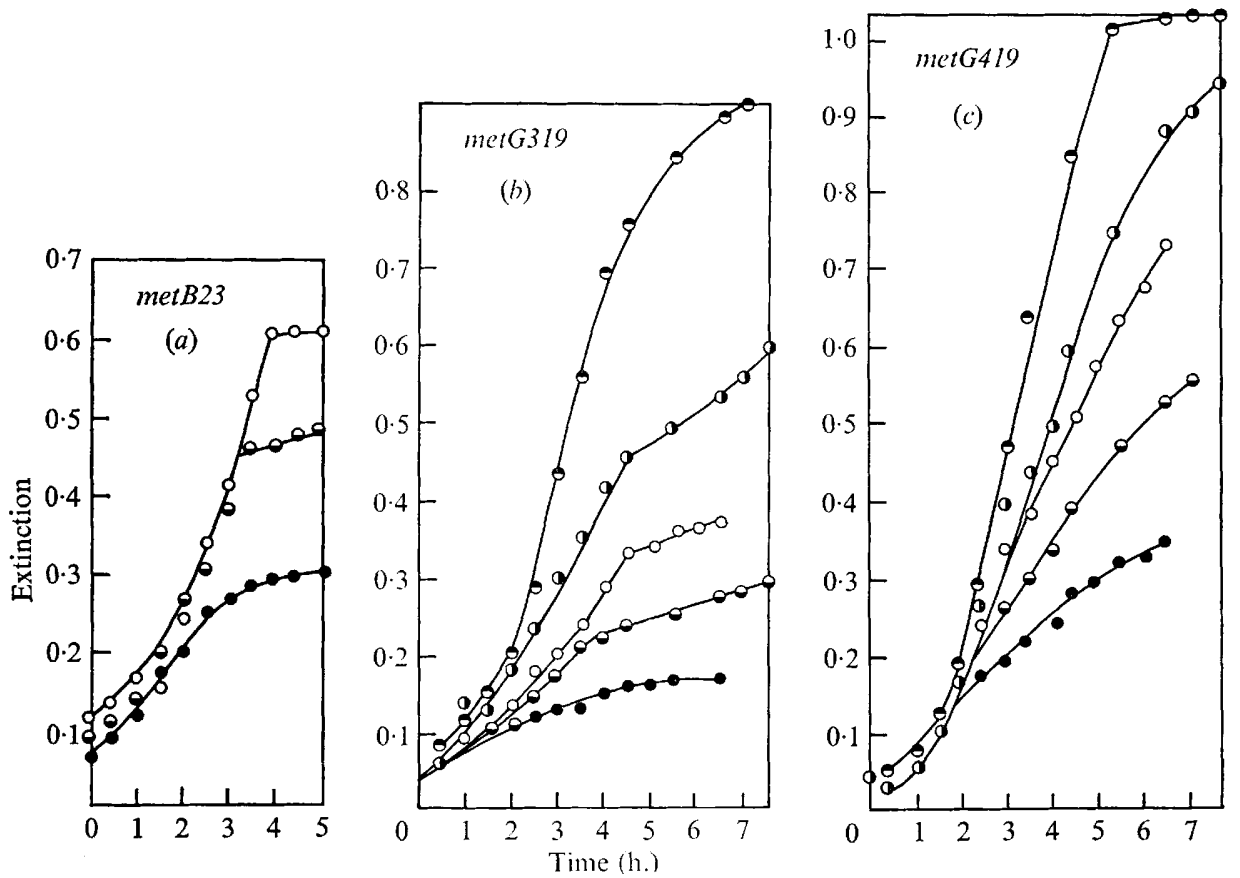

Fig. I. Growth of metB23, metG 319 and metG419 mutants of Salmonella typhimurium at different concentrations of DL-methionine. Overnight cultures were used to inoculate fresh MM medium containing DL-methionine at the required concentration. Cultures were shaken at $37^{\circ}$ and extinction readings taken at intervals. Results are plotted for metB23, $m t G_{3} I 9$ and $m t G_{4} I 9$ in $(a),(b)$ and $(c)$ respectively. The concentrations of DL-methionine were: $\ominus, 80 \mu \mathrm{M} ; 0,40 \mu \mathrm{M} ; 0,30 \mu \mathrm{M} \odot \ominus, 20 \mu \mathrm{M} ; \ominus$, I0 $\mu \mathrm{M}$.

The behaviour of the met $G$ mutants in the presence of the methionine analogues ethionine and norleucine did not support this view. Most methionine-requiring auxotrophs can grow and make protein for some time when ethionine or norleucine replace the methionine supplement, since the analogues can replace methionine in proteins. Met $G$ mutants, however, showed no growth at all in the presence of the analogues, indicating that a process which can utilize the analogues was altered. Since these analogues are not utilized in SAM synthesis (Gross, 1969) it seemed likely that the process altered was protein synthesis.

Protein synthesis in metG 319 and metB23 mutants: incorporation of $\left[{ }^{14} C\right]$ phenylalanine into the hot TCA-insoluble fraction. Since met $G$ mutants appeared to be abnormal in their growth kinetics it was decided to examine the effect of methionine starvation on protein synthesis in met $G$ mutants. Protein synthesis was observed by following 
the incorporation of $\left[{ }^{14} \mathrm{C}\right]$ phenylalanine into a hot TCA-insoluble fraction and by following the synthesis of the inducible enzyme D-serine deaminase. Results presented in Fig. 2 show that in the absence of methionine, incorporation of $\left[{ }^{14} \mathrm{C}\right]$ phenylalanine by $m t_{G} G_{19}$ and $m e t B 23$ was very much decreased when compared with incorporation by wild-type organisms. In the presence of $5 \mu \mathrm{M}$-DL-methionine the rate of incorporation by metG319 was stimulated for about $30 \mathrm{~min}$. but reached a maximum considerably lower than that for metB23 and wild type.

Protein synthesis in metG319 and metB23 mutants: Induction of D-serine deaminase. Protein synthesis was also estimated by following the induction of the enzyme D-serine

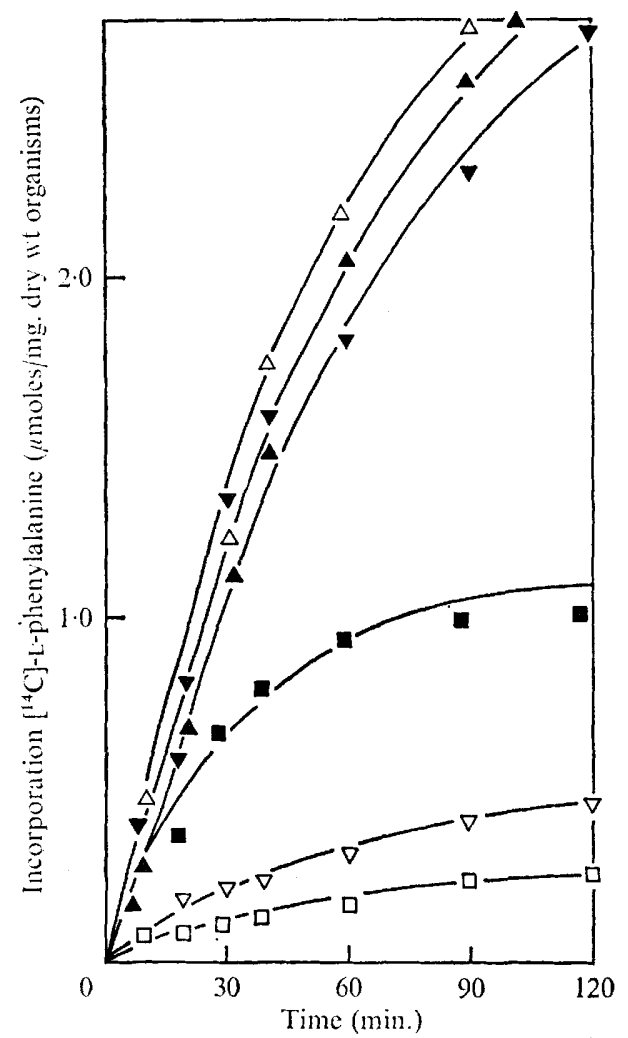

Fig. 2

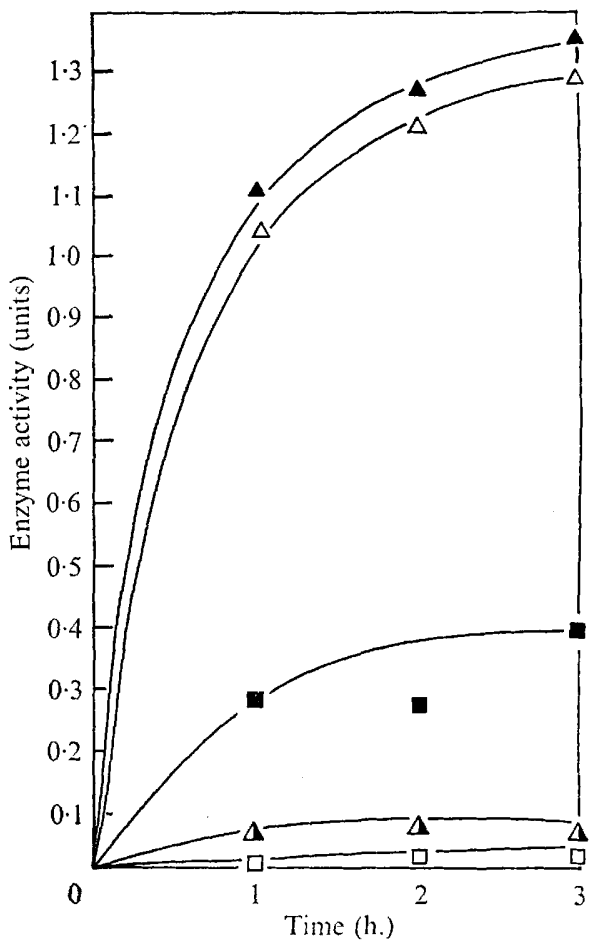

Fig. 3

Fig. 2. Incorporation of $\left[{ }^{14} \mathrm{C}\right]$ phenylalanine into protein by metB23 and metG 319 mutants. Exponentially growing bacteria were harvested, washed and used to inoculate MM medium containing the indicated supplements. Cultures were shaken at $37^{\circ}$ and $\mathrm{I} \mathrm{ml}$. samples taken at intervals into an equal volume of $10 \%$ trichloroacetic acid. Samples were treated as described in Methods and assayed for radioactivity. Plotting $\left[{ }^{14} \mathrm{C}\right]$ phenylalanine incorporation against

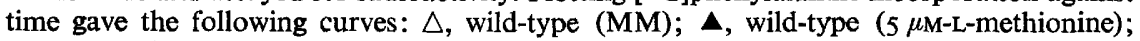
$\nabla, \operatorname{metB23}(\mathrm{MM}) ; \nabla$, metB23 (5 $\mu \mathrm{M}-\mathrm{L}-$ methionine); $\square, \operatorname{met} G_{319}(\mathrm{MM}) ; \square, \operatorname{met} G_{319}(5 \mu \mathrm{M}-$ L-methionine).

Fig. 3. Induction of D-serine deaminase synthesis in wild-type and met $G_{319}$ strains. D-serine ( $3 \mathrm{mM}$ ) was added to exponentially growing cultures, samples taken at intervals and assayed for D-serine deaminase activity. Assay procedure and rowth conditions are given in Methods. Plotting D-serine deaminase activity ( $\mu$ moles pyruvate formed/min./mg. protein) against time gave the following curves: $\square, \operatorname{met}_{3} 19(\mathrm{MM}) ; \Delta$, wild-type $(\mathrm{MM}) ; \mathbf{\square}, \operatorname{met}_{3}{ }_{39}$ (0.1 mM-DL-methionine); $\Delta$, wild-type (0.I mM-DL-methionine); $\Delta$, wild-type (MM, in absence of D-serine). 
deaminase, following addition of the inducer D-serine. Results presented in Fig. 3 show that in the absence of added methionine, metG 319 did not synthesize the enzyme even after addition of the inducer, whereas wild-type organisms began rapid synthesis of the enzyme directly after addition of the inducer. In the presence of O.I mM-DLmethionine, met $G_{319}$ synthesized D-serine deaminase at a rate somewhat less than that of the wild-type. These results confirmed that the met $G$ mutation very much decreased the overall rate of protein synthesis unless exogenous methionine were present.

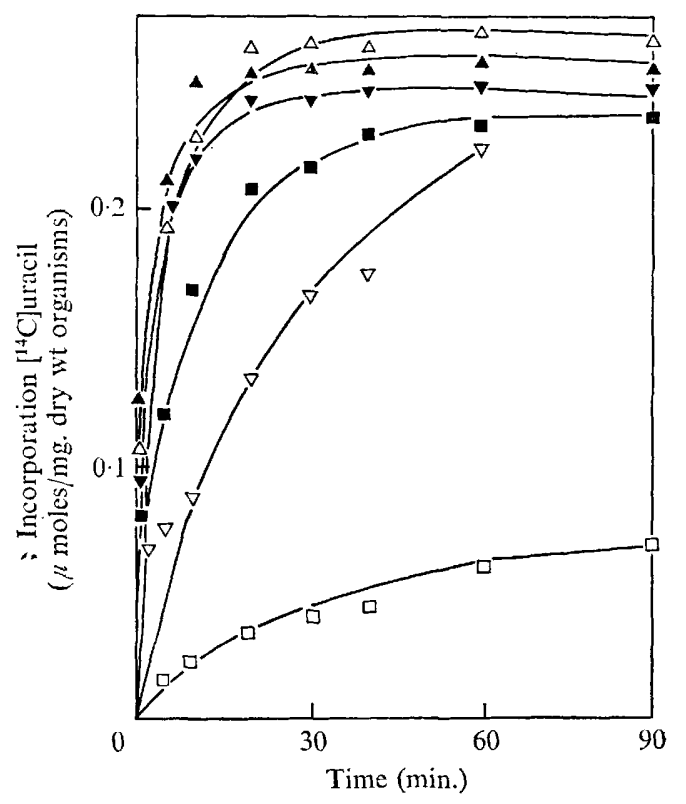

Fig. 4

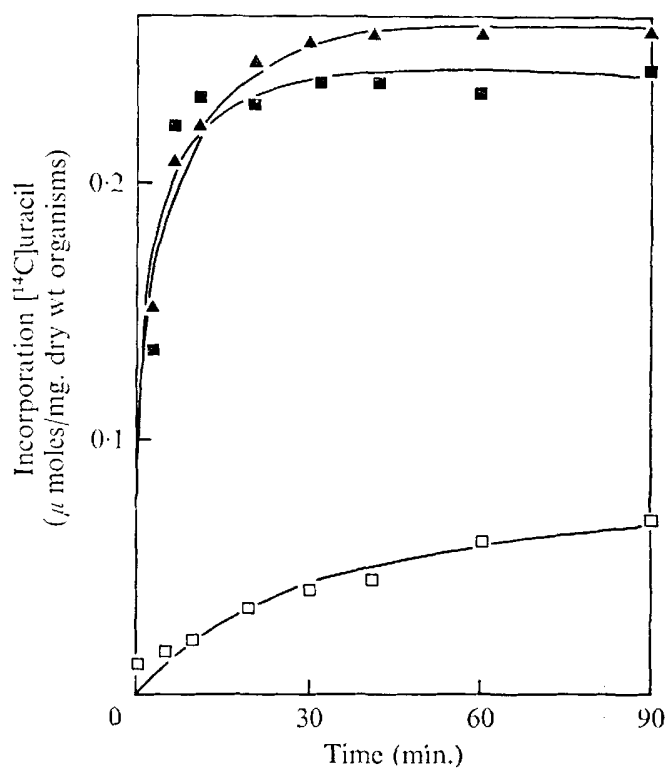

Fig. 5

Fig. 4. Incorporation of $\left[^{14} \mathrm{C}\right]$ uracil into RNA by met $B_{23}$ and metG $3^{I 9}$. Overnight cultures were used to inoculate fresh $\mathrm{MM}$ medium containing $\left[{ }^{14} \mathrm{C}\right]$ uracil and supplemented with methionine where indicated. Cultures were shaken at $37^{\circ}$ and $\mathrm{I} \mathrm{ml}$. samples taken at intervals into an equal volume of cold $10 \% \mathrm{TCA}$ and treated as described in Methods. Plotting $\left[{ }^{14}\right.$ C]uracil incorporation against time gave the following results: $\triangle$, wild-type (MM);

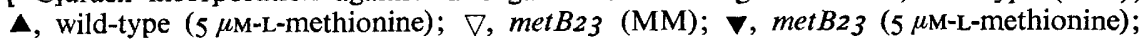
$\square, \operatorname{met}_{319}(\mathrm{MM}) ; \square, \operatorname{met} G_{319}$ ( $5 \mu \mathrm{M}$-L-methionine).

Fig. 5. Effect of chloramphenicol on $\left[{ }^{14} \mathrm{C}\right]$ uracil incorporation in met $G_{319}$. Experimental details were as described above, and chloramphenicol ( $150 \mu \mathrm{g} . / \mathrm{ml}$.) was added where indicated. Plotting $\left[{ }^{14} \mathrm{C}\right]$ uracil incorporation against time gave the following results; $\boldsymbol{\Delta}$, wildtype (+chloramphenicol); $\mathbf{n}, \operatorname{met} G_{3 I 9}\left(+\right.$ chloramphenicol); $\square$, met $G_{3 I 9}$ (no chloramphenicol).

RNA synthesis in metG319. Strains of bacteria which are 'stringent' in their synthesis of RNA are unable to synthesize RNA if starved of an amino acid. Chloramphenicol allows RNA synthesis under these conditions (Aronson \& Spiegelman, 196I). Results presented in Fig. 4 indicate that in the absence of methionine, incorporation of $\left[{ }^{14} \mathrm{C}\right]$ uracil into a cold TCA-insoluble fraction was much decreased in $m t G_{3} 19$ as compared with wild-type. Some incorporation occurred in $m e t B 23$ in the absence of methionine, possibly due to utilization of an existing methionine pool which, because of its defec- 
tive methionyl-sRNA synthetase, could not be used by metG319. In the presence of a low concentration of DL-methionine $(5 \mu \mathrm{M})$, incorporation of $\left[{ }^{14} \mathrm{C}\right]$ uracil was greatly increased in $m_{e t} G_{319}$ and $m e t B 23$. In $m e_{B 23}$ the rate and final degree of incorporation of $\left.{ }^{14} \mathrm{C}\right]$ uracil was indistinguishable from wild-type, whereas that of met $_{319}$ was still slightly less, probably due to the altered synthetase which prevented full utilization of the proffered methionine. These results indicate that RNA synthesis in met $G_{319}$ was stringently controlled. In the presence of $100 \mu \mathrm{g} . / \mathrm{ml}$. chloramphenicol, incorporation of $\left.{ }^{[14} \mathrm{C}\right]$ uracil was allowed in $m e t G_{319}$ even in the absence of added methionine and to an extent comparable to wild-type (Fig. 5).

\section{Table I. The effect of methionine-limitation on multiplication of phage P22.L4 in Salmonella typhimurium metG 319}

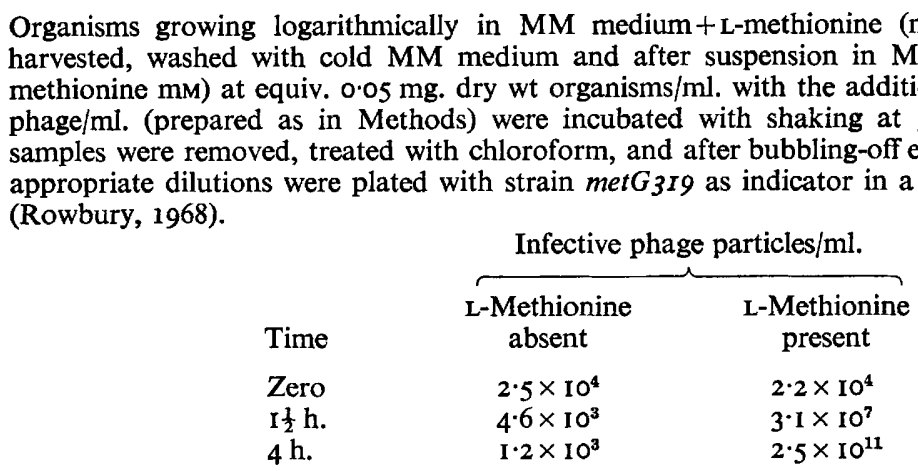

Synthesis of DNA in met $G$ mutants. The results so far described suggest that in the absence of methionine, protein synthesis rather than SAM synthesis was affected primarily in metG319. Measurements of DNA synthesis in the presence and absence of methionine supported this view. When protein synthesis is inhibited in bacteria, e.g. by adding chloramphenicol or limiting a required amino acid, any rounds of DNA synthesis at present in progress are completed but new rounds do not begin (Maaløe \& Hanawalt, 196I). For organisms growing in minimal medium with no gap between rounds of replication, there is generally about a $40 \%$ increase in DNA on amino acid starvation (Donachie, 1969). Limitation of SAM, on the other hand, allows a $100 \%$ increase in DNA (Lark I968).

When Salmonella typhimurium metG319 was shifted from minimal medium containing methionine (mM) to methionine-free medium there was an increase in DNA of $47 \%$ as compared with $4 \mathrm{I} \%$ in presence of chloramphenicol. Clearly, the lesion in metG3I9 allowed only very limited re-initiation of DNA synthesis and therefore affected protein synthesis rather than SAM synthesis. In addition, the formation of phage was completely inhibited in methionine-starved met $G_{319}$; the multiplication of $\mathrm{P}_{22} . \mathrm{L}_{4}$ was prevented unless methionine is added (Table $\mathrm{I}$ ).

Methionyl-sRNA formation in wild-type and metG319. To test the theory that the $m e t G$ phenotype resulted from decreased ability to catalyse the formation of methionylsRNA, the formation of methionyl-sRNA by extracts of wild type and metG 319 was followed over a period of $20 \mathrm{~min}$.; the results obtained are presented in Fig. 6. It can be seen that although the wild-type extract catalysed the rapid formation of methionylsRNA, the metG3I9 extract was practically devoid of activity. 
Methionyl-sRNA formation by a mixture of wild-type and met $G_{319}$ extracts. The inability of $m^{2} t_{3} I 9$ extract to catalyse methionyl-sRNA formation may mean that the $\operatorname{met} G$ gene specifies methionyl-sRNA synthetase and that mutation leads to a decrease in enzymic activity, but there are two other possible explanations. First, the $m e t G$ gene may be involved in the synthesis of a cofactor required for methionylsRNA synthetase activity; secondly, mutation in $\operatorname{met} G$ may result in accumulation of an inhibitor of methionyl-sRNA synthetase activity. To investigate these latter two

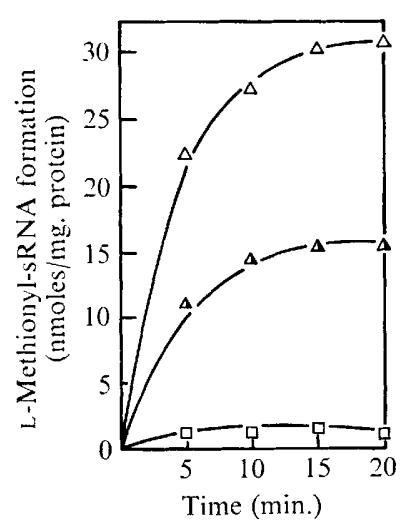

Fig. 6

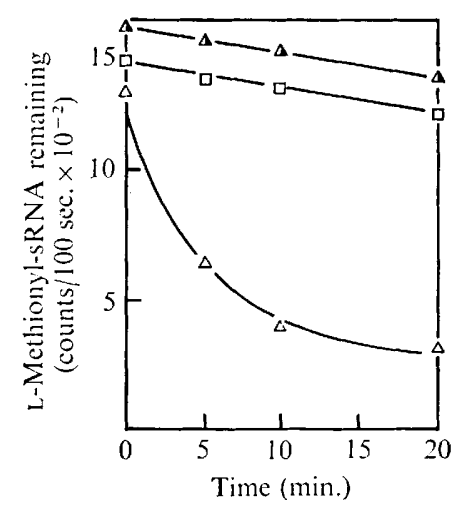

Fig. 7

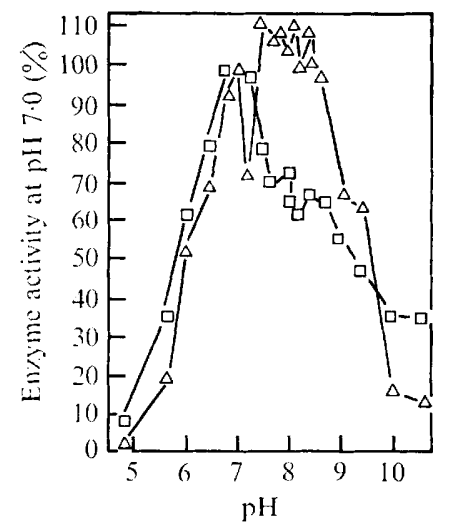

Fig. 8

Fig. 6. Methionyl-sRNA formation by a mixture of wild-type and metG 319 extracts. The assay mixture is described in the Methods. Plotting methionyl-sRNA formation against time gave the following curves: $\triangle$, wild-type; $\square, \operatorname{met} G_{319} ; \boldsymbol{\Delta}$, a mixture of equal quantities of wild-type and metG3r9 extracts.

Fig. 7. AMP-dependent release of methionine from methionyl-sRNA, catalysed by extracts of wild-type and metG 319 strains. Assay procedure as described in Methods. Plotting methionyl-sRNA remaining against time gave the following curves: $\triangle$, wild-type; $\square$, metG $319 ; \Delta$, wild-type in the absence of pyrophosphate.

Fig. 8. The effect of $\mathrm{pH}$ on the activity of methionyl-sRNA synthetase from wild-type and met $G_{319}$ extracts. Enzyme activity was determined by the $\left[{ }^{32} \mathrm{P}\right] \mathrm{PP}_{\mathrm{i}}$ exchange assay. The following buffers were used to obtain the required $\mathrm{pH}$ values: sodium acetate ( $\mathrm{pH} 4.8$ to $5 \cdot 6$ ), tris-maleate ( $\mathrm{pH}_{5} .6$ to 7.0 ), tris- $\mathrm{HCl}\left(\mathrm{pH}_{7} .0\right.$ to 8.9$)$ and glycine- $\mathrm{NaOH}(\mathrm{pH} 8.9$ to 10.6 ). Results were plotted, and the following curves were obtained: $\triangle$, wild-type; $\square$, met $G_{3} I 9$.

possibilities, the formation of methionyl-sRNA by a mixture of the two extracts was followed. The rationale behind this experiment was that if met $G$ specified methionylsRNA synthetase, then the combined activity of the two extracts would be equal to the sum of their individual activities when each was assayed alone. If the difference in activities were due to the presence of a cofactor in the wild type or an inhibitor in $m e t G$, then their combined activities would be greater or less than their individual activities unless the cofactor were limiting. The results presented in Fig. 7 show that the amount of methionyl-sRNA formed by a mixture of equal quantities of the two extracts was equal to the sum of the activities of the wild-type and met $G_{319}$ when assayed separately. It must therefore be concluded that the met $G$ gene of Salmonella typhimurium is the structural gene for methionyl-sRNA synthetase.

Amounts of in vivo charged $S R N A_{m+f}$ in wild-type and met $G_{319}$. In vitro studies on the formation of $\left[{ }^{3} \mathrm{H}\right]$ methionyl-sRNA provide good evidence that met $G$ mutants 
possess a methionyl-sRNA synthetase with decreased activity. To support this evidence, sRNA was extracted from mutant and wild-type bacteria and the percentage of sRNA ${ }_{m+f}$ 'charged' with methionine determined. Samples of extracted sRNA were subjected to periodate oxidation to destroy the amino acid-accepting capacity of 'uncharged' sRNA, and after removal of attached amino acids from oxidized and unoxidized samples they were recharged in vitro with $\left[{ }^{3} \mathrm{H}\right]$ methionine. By comparing the amounts of $\left[{ }^{3} \mathrm{H}\right]$ methionine attached to treated and untreated samples, the percentage of charged sRNA ${ }_{m+f}$ was calculated (Table 2). sRNA $_{m+f}$ from wild-type organisms was approximately $100 \%$ charged, whereas that from met $G_{319}$ was

Table 2. In vivo amounts of charged $s R A_{m+f}$

Organisms were grown on MM medium containing a low $(0.04 \mathrm{mM}$ ) or a high (I mM) concentration of DL-methionine. sRNA was extracted from the bacteria, half of it was oxidized with periodate, and then both untreated and treated samples were charged to completion with $\left[{ }^{3} \mathrm{H}\right]$ methionine.

$\begin{array}{lcc} & \text { sRNA }_{m+f} \text { charged (\%) } \\ \text { Strain } & \text { Low } & \begin{array}{c}\text { High } \\ \text { methionine }\end{array} \\ \text { Wild-type (HfrB2) } & 99.9 & 99 \cdot 8 \\ \text { met } G_{319} & 60 \cdot \mathrm{I} & 98 \cdot \mathbf{I} \\ \text { met } G_{419} & 59.5 & 97.2\end{array}$

Table 3. $K_{m}$ (methionine) values of methionyl-sRNA synthetases from wild-type and mutant strains of Salmonella typhimurium as measured by pyrophosphate exchange

The assay procedure was that described in the Methods, and the reaction mixture contained the following ranges of concentrations of L-methionine: 5 to $250 \mu \mathrm{M}$ for $\mathrm{HfrB} 2$, I.O to $2.5 \mathrm{mM}$ for $m_{e t} G_{319}$, and $\mathrm{I} \cdot 0$ to $5.0 \mathrm{mM}$ for $m t G_{419}$.

\begin{tabular}{lc}
$\quad$ Strain & \multicolumn{1}{c}{$K_{m}$} \\
Wild-type (HfrB2) & $\mathrm{I} \cdot 8 \times 10^{-5} \mathrm{M}$ \\
metG3I9 & $\mathrm{I} \cdot 0 \times 1 \mathrm{IO}^{-2} \mathrm{M}$ \\
metG 419 & $\mathrm{I} \cdot 0 \times 10^{-3} \mathrm{M}$
\end{tabular}

approximately $60 \%$ charged. Taking into account the very much decreased activity of the mutant enzyme, it is surprising that this figure was not lower. However, Martin, Yegian \& Stent (1963) found that under conditions of methionine starvation most of the methionine-accepting capacity of $\mathrm{sRNA}_{m+f}$ was protected against periodate oxidation. These authors later proposed (Yegian, Stent \& Martin, I966) that this protection might stem from $N$-formylmethionine which became trapped on its sRNA due to cessation of growth of polypeptide chains.

$A M P$-dependent releases of methionine from methionyl-sRNA. The above results show that extracts of met $G_{3} I 9$ were very low in their ability to form methionyl-sRNA. However, the formation of this compound occurred in two stages:

(I) methionine $+\mathrm{ATP}+$ enzyme $\rightleftharpoons$ methionine-AMP-enzyme $+\mathrm{PP}_{1}$;

(2) methionine-AMP-enzyme + sRNA $\mathrm{A}_{m} \rightleftharpoons$ methionyl-sRNA ${ }_{m}+\mathrm{AMP}+$ enzyme.

To determine whether reaction (2), the 'transfer' step, was affected, the release of methionine from methionyl-sRNA, catalysed by extracts of wild-type and met I $_{319}$ organisms, was followed. The results (Fig. 7) showed that only the wild-type extract catalysed the release of methionine to any extent. This would suggest that met $G_{319}$ 
lacks transfer reaction activity; but it can be seen that wild-type extract was unable to catalyse this reaction when pyrophosphate was not present in the reaction mixture. This suggests that reversal of the transfer step also required reversal of reaction (I) so that lack of activity with $m^{2} G_{3} I 9$ extract may reflect an alteration in either partial reaction.

$K_{m}$ (methionine) determinations for methionyl-sRNA synthetases from wild-type and $m e t G_{319}$. Preliminary attempts to determine the affinity of the metG319 enzyme for methionine by using the acylation reaction were largely unsuccessful for technical reasons. It was therefore decided to use the methionine-dependent $\left.{ }^{32} \mathrm{P}\right]$ pyrophosphate exchange assay which allowed much higher concentrations of methionine to be used. This assay measures reaction (I) above, the 'activation' step, so that it was also possible to see whether this stage of the reaction was affected by the met $G$ mutation. The results (Table 3 ) show that both $m^{2} t G_{3} I 9$ and $m^{2} t G_{4} I 9$ had greatly increased $K_{m}$ (methionine) values as compared with wild-type.

Effect of $p H$ on the activity of methionyl-sRNA synthetase from wild-type and met $G_{319}$. It was of interest to investigate whether the decreased activity of methionyl-sRNA synthetase from $m e t G$ mutants was associated with an alteration in its $\mathrm{pH}$ optimum. The rate of pyrophosphate exchange was determined with a range of buffers of different $\mathrm{pH}$ values. The results are presented in Fig. 8. The activities of wild-type and met ${ }_{319}$ enzymes showed little activity below $\mathrm{pH} 5$ but increased with $\mathrm{pH}$ until $\mathrm{pH} 7 \cdot 0$ was reached. At $\mathrm{pH}$ values greater than $7 \cdot 0$, activity decreased until $\mathrm{pH} 7 \cdot 2$ was reached. From this point on the behaviour of wild-type and $m^{2} t G_{3} 19$ differed considerably. At $\mathrm{pH}$ values greater than $7 \cdot 2$ the activity of $m^{2} t G_{3} 19$ continued to decrease whereas that of the wild-type increased to a new maximum at $\mathrm{pH} 7.5$ and remained fairly constant until $\mathrm{pH} 8.5$. With $\mathrm{met}_{3}{ }_{319}$ only a shoulder of activity remained between $\mathrm{pH} 7 \cdot 9$ and $8 \cdot 8$, suggesting that in the wild-type organisms the bulk of methionyl-sRNA synthetase activity was associated with a broad $\mathrm{pH}$ optimum and that $m e t G$ organisms largely lacked this component.

Chromatography of wild-type and met G319 extracts on DEAE-cellulose. The different behaviour of metG319 and wild-type methionyl-sRNA synthetase when measured over a range of $\mathrm{pH}$ values reflected the difference in enzymic activities of the two strains. To investigate the possibility that this difference was reflected in other physicochemical properties, enzymic extracts were subjected to chromatography on DEAEcellulose. The results in Fig. 9(a) for the wild-type and Fig. 9(b) for met $G_{319}$ show that both enzymes had very similar elution profiles, the slight displacement of the met $G_{3} I 9$ peak in Fig. $9(b)$ being within the limits of variation imposed by the experimental technique.

However, enzyme from both strains was eluted in two more or less equal peaks of activity. The reason for this may be that, as suggested by Cerhová \& Rychlík (I967) for Escherichia coli, Salmonella typhimurium contains two species of methionyl-sRNA synthetase, one catalysing the attachment of methionine to $\mathrm{sRA}_{\mathrm{m}}$ and the other to $\mathrm{sRNA}_{\mathrm{f}}$. If this be so, then this must reflect a species difference between $S$. typhimurium and E. coli, because Hartley \& Heinrikson (1967), Cassio \& Waller (1968) and Bruton \& Hartley (1968) have all shown that in E. coli a single enzyme catalyses the attachment of methionine to both types of sRNA. In view of these results it seems unlikely that there are two species of methionyl-sRNA synthetase in S. typhimurium. Alternatively, it may be that the smaller $\mathrm{pH}$ peak and one of the elution peaks represents a 
breakdown product or a precursor of the mature enzyme, or it may represent active subunits of an oligomeric protein. The fact that native methionyl-sRNA synthetase can exist as active subunits is suggested by the results of Hartley \& Heinrikson (I967) and Bruton \& Hartley (1968).
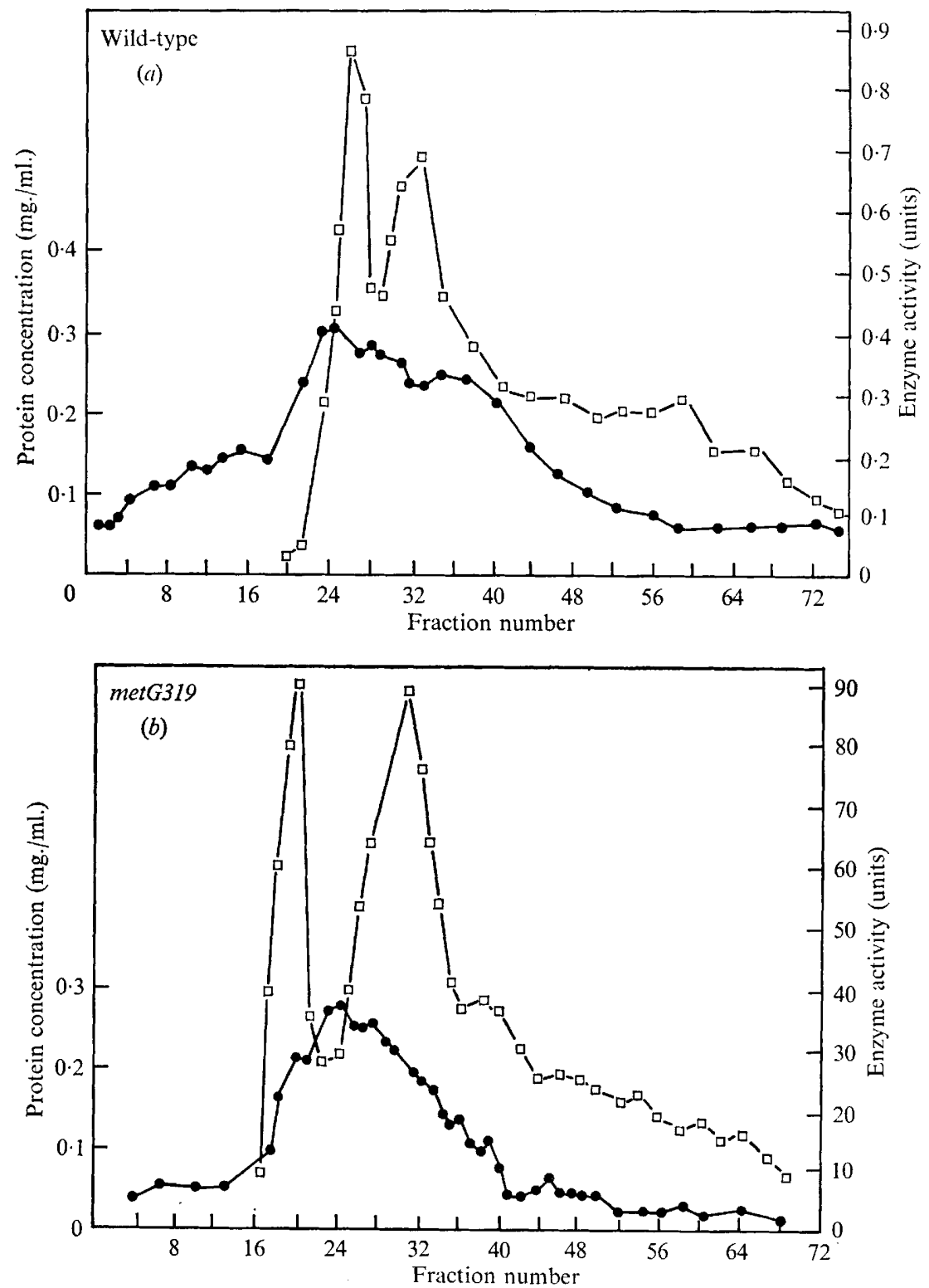

Fig. 9. DEAE-cellulose chromatography of wild-type and met $G_{3} I 9$ methionyl-sRNA synthetase. Fractions were assayed for enzyme activity by the pyrophosphate exchange assay. Results obtained for wild type and $m^{2} t G_{3} I 9$ are presented in $(a)$ and $(b)$ respectively. Enzyme activity expressed as $\mu$ moles pyrophosphate exchanged $/ 15 \mathrm{~min} . / \mathrm{mg}$. protein for wild-type and $\mu$ moles pyrophosphate exchanged $/ 15 \mathrm{~min} . / \mathrm{mg}$. protein for met $G_{319} ; \square$, enzyme activity; $\bullet$, protein concentration. 
Gel-filtration on Sephadex G-20o. The behaviour of methionyl-sRNA synthetase on DEAE-cellulose at a range of $\mathrm{pH}$ values might be expected to reflect the ionic properties of the enzyme molecule. To investigate the possibility of a difference in the molecular sizes of wild-type and mutant enzymes, they were subjected to gel-filtration
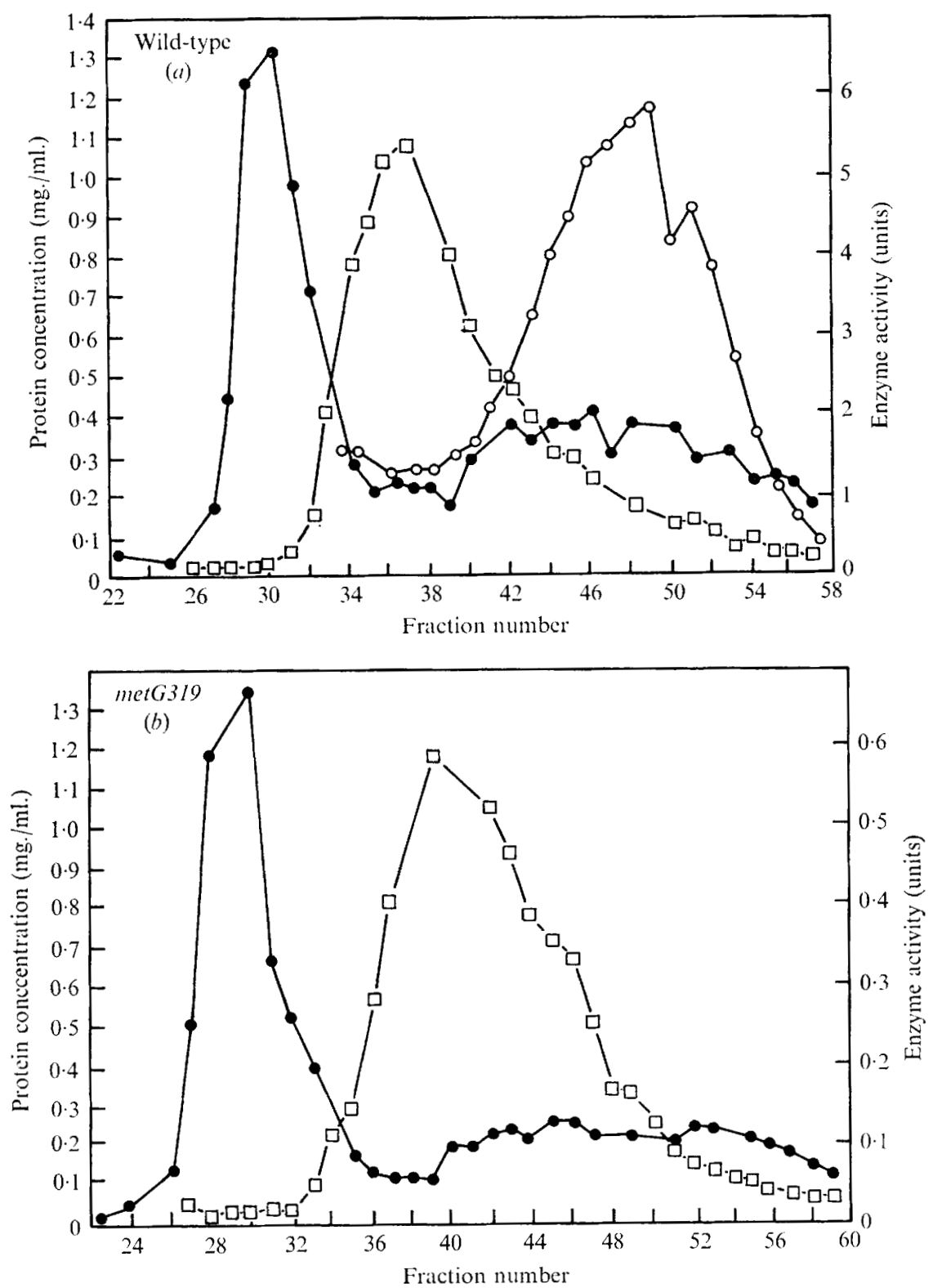

Fig. 10. Gel-filtration of wild type and metG 319 methionyl-sRNA synthetases on Sephadex G-200. Fractions were assayed for enzyme activity by the pyrophosphate exchange assay. Results obtained for wild type and met $G_{3} 19$ are presented in $(a)$ and $(b)$ respectively. Enzymic activity, $\square$, as $\mu$ moles pyrophosphate exchanged $/ 15 \mathrm{~min} . / \mathrm{mg}$. protein, and protein concentration, $\boldsymbol{\theta}$, are plotted for both strains, and the elution profile of serum albumin, $O$, is included in $(a)$. 
on Sephadex G-200. The results (Fig. Io(a) for wild-type, Fig. Io (b) for met 3 $_{319}$ ) showed that there was no significant difference between the elution patterns of wildtype and $\operatorname{met} G$ mutants, the slight displacement of the met $G_{3} I 9$ peak in Fig. $10(b)$ being within the limits of variation imposed by the experimental technique.

Amounts of the methionine biosynthetic enzymes in Salmonella typhimurium met $G_{319}$ and metG4I9. Since protein synthesis in strain metG $_{319}$ is limited by the supply of methionyl-sRNA, it was interesting to measure the amounts of the methionine biosynthetic enzymes under conditions where growth was limited by methionine supply, since it is the aminoacyl-sRNA rather than the free amino acid which acts as co-repressor in some biosynthetic pathways (Neidhardt, 1966). Table 4 shows representative

\section{Table 4. Amounts of methionine-biosynthetic enzymes in Salmonella typhimurium met $G_{319}$ and met $G_{419}$}

\begin{tabular}{|c|c|c|c|c|}
\hline \multirow{2}{*}{$\begin{array}{l}\text { Organisms } \\
\text { methionine) } \\
\text { Methods. }\end{array}$} & \multirow[t]{2}{*}{$\begin{array}{l}\text { were grown at } 30^{\circ} \\
\text { or mM-L-methionine }\end{array}$} & $\begin{array}{l}\text { in } \mathrm{MM} \text { medium } \\
\text { (high methionine). }\end{array}$ & \multicolumn{2}{|c|}{$\begin{array}{l}\text { plus } 0.02 \mathrm{mM}-\mathrm{L}-\mathrm{methionine} \mathrm{(low} \\
\text { Enzyme assays as described in }\end{array}$} \\
\hline & & $\begin{array}{l}\text { Cystathionine } \\
\text { synthetase }(\mu \text { mole/ } \\
\text { mg. dry wt/h.) }\end{array}$ & $\begin{array}{c}\text { Cystathionase } \\
\text { ( } \mu \text { moles pyruvate/ } \\
\text { mg. dry wt/h.) }\end{array}$ & $\begin{array}{l}\text { Homocysteine } \\
\text { methylase } \\
\text { ( } \mu \text { moles } \\
\text { methionine } \\
\text { formed/mg. } \\
\text { dry } w / / h .)\end{array}$ \\
\hline $\mathrm{HfrB2}$ & $\begin{array}{l}\text { Low } \\
\text { High }\end{array}$ & $\begin{array}{l}0.200 \\
0.061\end{array}$ & $\begin{array}{l}0.53 \\
0.40\end{array}$ & $\begin{array}{l}0.33 \\
0.08\end{array}$ \\
\hline $\operatorname{met}_{319}$ & $\begin{array}{l}\text { Low } \\
\text { High }\end{array}$ & $\begin{array}{l}0.030 \\
0.015\end{array}$ & $\begin{array}{l}0.93 \\
0.45\end{array}$ & $\begin{array}{l}0.17 \\
0.09\end{array}$ \\
\hline $\operatorname{met} G_{419}$ & $\begin{array}{l}\text { Low } \\
\text { High }\end{array}$ & $\begin{array}{l}0.065 \\
0.018\end{array}$ & $\begin{array}{l}0.93 \\
0.78\end{array}$ & $\begin{array}{l}0.28 \\
0.09\end{array}$ \\
\hline
\end{tabular}

results for organisms grown at $30^{\circ}$ with $0.02 \mathrm{mM}-\mathrm{L}-$ methionine (low methionine) or mM-L-methionine (high methionine). Values for cystathionine synthetase and the homocysteine methylase complex were lower than in wild-type (preliminary results suggest this also applies to the amounts of the methionine-specific aspartokinase and homoserine dehydrogenase). The values of cystathionase were somewhat higher than in wild-type; this observation has been repeated several times. It therefore appears that methionyl-sRNA is not the co-repressor, at least not for the whole biosynthetic pathway, since conditions which restrict methionyl-sRNA synthetase in met $G$ mutants lead to a slight repression of cystathionine synthetase, the homocysteine methylase complex and the methionine-specific aspartokinase and homoserine dehydrogenase. This repression may be due to a build-up of free methionine because it cannot be readily activated. The de-repression of cystathionase does not fit this pattern and is not at present explicable.

\section{DISCUSSION}

The present study investigated the effect of the met $G$ mutation on the growth characteristics and protein, RNA and DNA synthesis in Salmonella typhimurium. Auxotrophic mutants of Escherichia coli analogous to met $G$ have also been isolated with requirements for tryptophan (Doolittle \& Yanofsky, 1968; Kano, Matsushiro \& Shimura, I968), histidine (Nass \& Neidhardt, 1966) and glycine (Folk \& Berg, 1968). 
Of these, the tryptophanyl-sRNA synthetase mutants have been shown to possess growth characteristics similar to those of met $G$ mutants (Doolittle \& Yanofsky, I968; Ito, Hiraga \& Yura, I969). It was possible that the met $G$ mutants were altered in SAM synthetase rather than in methionyl-sRNA synthetase. However, the very low rate of incorporation of $\left[{ }^{14} \mathrm{C}\right]$ phenylalanine into protein in $\mathrm{MM}$ medium (Fig. 2), lack of synthesis of D-serine deaminase in the presence of inducer (Fig. 3), and decrease of DNA (Table I) and RNA (Fig. 4) synthesis in met $G$ mutants all establish that protein synthesis is affected in met $G$ mutants. Further experiments on the synthesis of methionylsRNA in vitro showed that met $G$ mutants possessed a methionyl-sRNA synthetase with much decreased affinity for methionine. Results obtained using the pyrophosphate exchange assay support this conclusion and show that the $K_{m}$ (methionine) values of methionyl-sRNA synthetases from met $G$ mutants are greatly increased.

The release of $\left[{ }^{3} \mathrm{H}\right]$ methionine from $\left[{ }^{3} \mathrm{H}\right]$ methionyl-sRNA was catalysed by a wildtype extract but not by met $G_{319}$, suggesting that the latter is very restricted in its ability to catalyse this reaction. However, since removal of methionine from sRNA appears to require reversal of both partial reactions, this may reflect only the defective first step. Clarification of this problem might result from a study of the transfer of radioactive methionine from chemically synthesized methionyl-adenylate to sRNA.

Evidence that methionyl-sRNA is not the co-repressor of methionine biosynthesis is presented in Table 4; further support comes from studies of methionine-analogue resistant strains in which the biosynthetic enzymes are de-repressed in two groups of resistant strains but in neither are there obvious alterations in amounts of methionylsRNA synthetase or in sRNA(T. S. Gross \& R. J. Rowbury, unpublished). Since limitation of methionine will inevitably limit $N$-formyl-methionyl-sRNA also, it seems unlikely that this compound is involved in repression. Methionine may either act directly as co-repressor or, as in Escherichia coli (Greene, Su \& Holloway, 1970), SAM may have a role. So far no evidence for altered SAM metabolism has been obtained in de-repressed strains of Salmonella typhimurium.

The experiments on the multiplication of $\mathrm{P}_{22} \mathrm{~L}_{4}$ phage in met $G_{319}$ demonstrate that the phage is dependent on the host methionyl-sRNA synthetase and does not produce its own specific enzyme or an active altered host enzyme. In at least one case, an inactive synthetase is activated by the presence of phage in Escherichia coli (Neidhardt, I966).

This work was done whilst one of us (T.S. G.) was in receipt of a Science Research Council Studentship.

\section{REFERENCES}

Aronson, A. I. \& Spiegelman, S. (196I). Protein and ribonucleic acid synthesis in a chloramphenicol inhibited system. Biochimica et biophysica acta 53, 70-84.

Böck, A., Faiman, L. E. \& NeIDhardT, F. C. (1966). Biochemical and genetic characterization of a mutant of Escherichia coli with a temperature-sensitive valyl ribonucleic acid synthetase. Journal of Bacteriology 92, 1076-I082.

BöcK, A. \& NeIDHARDT, F. C. (I966). Location of the structural gene for glycyl ribonucleic acid synthetase by means of a strain of Escherichia coli possessing an unusual enzyme. Zeitschrift für Vererbungslehre $98,187-192$.

BRUton, C. J. \& HARTLEY, B. S. (1968). Subunit structure and specificity of methionyl-transfer-ribonucleic acid synthetase from Escherichia coli. Biochemical Journal ro8, 28 I-288. 
CAssio, D. \& Waller, J.-P. (1968). Études de la méthionyl-tRNA synthétase d'Escherichia coli. III. Dissociation en sous-unités actives par action d'un facteur extringèque. European Journal of Biochemistry 5, 33-4x.

CERHOVÁ, M. \& RYCHLík, I. (1967). Isolation of two methionyl-tRNA synthetases from Escherichia coli. Collection of Czechoslovakian Chemical Communications 32, 3808-381 I.

DAVIS, B. D. \& MingroLI, F. S. (1950). Mutants of Escherichia coli requiring methionine or vitamin $\mathbf{B}_{22}$. Journal of Bacteriology 6o, 17-28.

DONACHIE, W. D. (1969). Control of cell division in Escherichia coli: Experiments with thymine starvation. Journal of Bacteriology 100, 260-268.

DoolrtTLE, W. F. \& YANOFSKY, C. (I968). Mutants of Escherichia coli with an altered tryptophanyltransfer ribonucleic acid synthetase. Journal of Bacteriology 95, I283-1294.

EIDLIC, L. \& NeIDHARDT, F. C. (1965). Role of valyl sRNA synthetase in enzyme repression. Proceedings of the National Academy of Sciences of the United States of America 53, 539-543.

Fangman, W. L. \& Neidhardt, F. C. (1964). Demonstration of an altered aminoacyl ribonucleic acid synthetase in a mutant of Escherichia coli. Journal of Biological Chemistry 239, 1839-1843.

FoLK, W. R. \& BERG, P. (1968). Mutant glycyl-tRNA synthetase and the resulting glycine auxotrophy in E. coli. Federation Proceedings. Federation of American Societies for Experimental Biology 27, 796 .

Greene, R. C., Su, C. H. \& Holloway, R. (1970). S-adenosyl-methionine synthetase mutants of Escherichia coli $\mathrm{K} \mathrm{I} 2$ with impaired control of methionine biosynthesis. Biochemical and Biophysical Research Communications 38, 1120-1126.

Gross, T. S. (1969). Ph.D. Thesis, University of London.

Gross, T. S. \& RowburY, R. J. (1969). Methionyl-tRNA synthetase mutants of Salmonella typhimurium which have normal control of their methionine biosynthetic enzymes. Biochimica et biophysica acta $184,233-236$.

Hartley, R. L. \& Heinrikson, B. S. (1967). Purification and properties of methionyl-transferribonucleic acid synthetase from Escherichia coli. Biochemical Journal 105, 17-24.

Hervé, G. \& Chapeville, F. (I963). Specificité des enzymes d'activation à l'égard des acides ribonucléiques estérifies par les acides aminés. Biochimica et biophysica acta 76, 493-500.

HiraGa, S., Ito, K., HAMAdA, K. \& YURA, T. (I967). A new regulatory gene for the tryptophan operon of Escherichia coli. Biochemical and Biophysical Research Communications 26, 522-527.

Ito, K., HiRAGA, S. \& YURA, T. (1969). Tryptophanyl transfer RNA synthetase and repression of the tryptophan operon in the trpS mutant of Escherichia coli. Genetics 6r, 521-538.

Kano, Y., Matsushiro, A. \& Shimura, Y. (I968). Isolation of the novel regulatory mutants of the tryptophan biosynthetic system in Escherichia coli. Molecular and General Genetics 102, 15-26.

LARK, C. (1968). Effect of the methionine analogues, ethionine and norleucine, on DNA synthesis in Escherichia coli $15 \mathrm{~T}^{-}$. Journal of Molecular Biology 31, 40I-4r4.

LAYNE, E. (1957). In Methods in Enzymology, vol. 3, p. 451. Edited by S. P. Colowick \& N. O. Kaplan. New York: Academic Press.

MaAløe, O. \& Hanawalt, P. C. (I96I). Thymine deficiency and the normal DNA replication cycle. I. Journal of Molecular Biology 3, I44-I55.

MANS, R. J. \& NovelLI, G. D. (I96I). Measurement of the incorporation of radioactive amino acids into protein by a filter paper disc method. Archives of Biochemistry and Biophysics 94, 48-53.

Martin, E. M., Yegian, C. \& Stent, G. S. (1963). The intracellular condition of soluble ribonucleic acid in Escherichia coli subjected to amino acid starvation. Biochemical Journal 88, 46 P.

NASS, G. \& NEIDHARDT, F. C. (1966). Histidyl-sRNA synthetase and enzyme repression in Escherichia coli. Bacteriological Proceedings, p. 87.

NeAle, S. \& Tristram, H. (1963). Effects of $O$-methyl-DL-serine on growth and protein synthesis in Escherichia coli. Journal of Bacteriology 86, $1241-1250$.

NetDHARDT, F. C. (1966). Role of amino acid activating enzymes in cellular physiology. Bacteriological Reviews 30, 70I-7I9.

Rotн, J. R. \& AMEs, B. N. (I966). Histidine regulatory mutants in Salmonella typhimurium. II. Histidine regulatory mutants having altered histidyl-tRNA synthetase. Journal of Molecular Biology 22, 325-334.

ROwBURY, R. J. (1968). The inhibitory action of $\alpha$-methylmethionine on Escherichia coli. Journal of General Microbiology 52, 223-230. 
Rowbury, R. J., LAwrence, D. A. \& SMith, D. A. (1968). Regulation of the methionine specific $\beta$-aspartokinase and homoserine dehydrogenase of Salmonella typhimurium. Journal of General Microbiology 54, 337-342.

RowbURY, R. J. \& Woods, D. D. (196I). Further studies on the repression of methionine synthesis in Escherichia coli. Journal of General Microbiology 24, I29-144.

RowBURY, R. J. \& Woons, D. D. (1966). The regulation of cystathionine formation in Escherichia coli. Journal of General Microbiology 42, 155-163.

Silbert, D. F., Fink, G. R. \& Ames, B. N. (1966). Histidine regulatory mutants in Salmonella typhimurium. III. A class of regulatory mutants deficient in tRNA for histidine. Journal of Molecular Biology 22, 335-347.

SмITH, D. A. \& CHILDS, J.D. (1966). Methionine genes and enzymes of Salmonella typhimurium. Heredity 2x, 265-286.

Smith, H. O. \& Levine, M. (1967). A phage P 22 gene controlling integration on prophage. Virology 3I, 207-216.

WiJesundera, S. \& Woons, D. D. (1962). The catabolism of cystathionine by Escherichia coli. Journal of General Microbiology 29, 353-366.

YANIF, M., JACOB, F. \& GROS, F. (I965). Mutations thermosensibles des systems activant la valine chez E. coli. Bulletin de la Société de Chimie Biologique 47, 1609-1656.

Yegian, C. D., Stent, G. S. \& Martin, E. M. (1966). Intracellular conditions of Escherichia coli transfer RNA. Proceedings of the National Academy of Sciences of the United States of America $55,839-846$. 